\title{
In vivo biometry and carcass characteristics of lambs in different finishing systems
}

\author{
Biometria in vivo e características de carcaça de cordeiros em \\ diferentes sistemas de terminação
}

\author{
Juliano Henriques da Motta $^{1 *}$; Cleber Cassol Pires ${ }^{2}$; Ana Maria Osorio Dias 3 ; \\ Verônica Gindri Manzoni ${ }^{3}$; Andressa Ana Martins ${ }^{4}$; Luiza Ilha Borges ${ }^{5}$; William \\ Soares Teixeira ${ }^{3}$, Natálie Viero Batista ${ }^{6}$; Gabriela Carvalho ${ }^{6}$; Juliene da Silva Rosa ${ }^{6}$
}

\begin{abstract}
The aim of this study was to assess the influence of different finishing systems on the in vivo measurements, quantitative and qualitative carcass characteristics, commercial cut ratio, and shoulder tissue composition of lambs. Thirty-two male lambs were distributed in four finishing systems with eight replications each, as follows: suckling lambs on pasture; suckling lambs in confinement, with access to creep-feeding containing corn bran and soybean meal; weaned lambs fed roughage, characterized by ad libitum supply of alfalfa hay; and weaned lambs fed concentrate, composed of oat grain and soybean meal. The lambs were slaughtered as they reached the pre-set live weight at slaughtering of $30 \mathrm{~kg}$. Most of the in vivo biometry variables were not significant $(\mathrm{P}>0.05)$ when comparing the finishing systems, except for hindlimb height and thoracic perimeter. Regarding the quantitative carcass characteristics, all variables differed $(\mathrm{P}<0.05)$ between systems, except for carcass length, leg width, and subcutaneous fat thickness. For the qualitative carcass characteristics, only the fatness and carcass conformation presented significant differences $(\mathrm{P}<0.05)$. Most in vivo measurements and the proportion of carcass cuts were not influenced by finishing systems. Weaned lambs fed an exclusive concentrate diet presented leaner carcasses with an inferior conformation when compared to the other finishing systems. Suckling lambs in confinement presented shoulders with a higher fat deposition when compared to those weaned. Suckling lambs both on pasture and in confinement presented a superiority in the quantitative carcass characteristics when compared to weaned lambs.
\end{abstract}

Key words: Tissue composition. Body measurement. Sheep.

1 Discente, Curso de Doutorado, Programa de Pós-Graduação em Zootecnia, Universidade Federal do Rio Grande do Sul, UFRGS, Porto Alegre, RS, Brasil. E-mail: julianomotta-06@hotmail.com

2 Prof. Dr., Departamento de Zootecnia, Universidade Federal de Santa Maria, UFSM, Santa Maria, RS, Brasil. E-mail: pirescleber@hotmail.com

3 Discentes, Curso de Doutorado, Programa de Pós-Graduação em Zootecnia, UFSM, Santa Maria, RS, Brasil. E-mail: anamariaodias@hotmail.com; vemanzoni@hotmail.com; miojo_william@hotmail.com

4 Dra em Zootecnia, UFSM, Santa Maria, RS, Brasil. E-mail: dess.a@hotmail.com

5 Discente, Curso de Mestrado, Programa de Pós-Graduação em Zootecnia, Universidade Estadual de Santa Catarina, UDESC, Chapecó, SC, Brasil. E-mail: luizaborges29@gmail.com

6 Discentes, Curso de Graduação em Zootecnia, UFSM, Santa Maria, RS, Brasil. E-mail: viero.natalie@gmail.com; carv-gabi@ hotmail.com; juliener22@gmail.com

* Author for correspondence 


\section{Resumo}

O objetivo do presente estudo foi avaliar a influência dos diferentes sistemas de terminação sobre as mensurações in vivo, as características quantitativas e qualitativas da carcaça, a proporção dos cortes comerciais e a composição tecidual da paleta de cordeiros. Foram utilizados 32 cordeiros machos, distribuídos em quatro sistemas de terminação com oito repetições cada, conforme a seguir: cordeiros lactentes em pastagem; cordeiros lactentes em confinamento, com acesso ao creep-feeding contendo farelo de milho e soja; cordeiros desmamados com volumoso, caracterizado pelo fornecimento $a d$ libitum de feno de alfafa; e cordeiros desmamados com concentrado, composto por grão de aveia e farelo de soja. Os cordeiros foram abatidos à medida que atingiram o peso vivo de abate pré-estabelecido de $30 \mathrm{~kg}$. A maioria das variáveis de biometria in vivo não foram significativas $(\mathrm{P}>0,05)$ entre os sistemas de terminação, com exceção da altura do posterior e do perímetro torácico. Quanto às características quantitativas da carcaça, todas a variáveis foram diferentes $(\mathrm{P}<0,05)$ entre os sistemas, exceto o comprimento de carcaça, a largura de perna e a espessura de gordura subcutânea. Para as características qualitativas da carcaça, apenas o estado de engorduramento e a conformação apresentaram diferenças significativas $(\mathrm{P}<0,05)$. A maioria das mensurações in vivo e as proporções dos cortes da carcaça não sofreram influência dos sistemas de terminação. Os cordeiros desmamados com dieta exclusiva de concentrado, apresentaram carcaças magras com conformação inferior aos demais sistemas de terminação. Os cordeiros lactentes em confinamento apresentaram paletas com maior deposição de gordura do que os desmamados. Tanto cordeiros lactentes em pastagem, quanto em confinamento, apresentaram superioridade nas características quantitativas da carcaça em relação aos cordeiros desmamados.

Palavras-chave: Composição tecidual. Mensuração corporal. Ovinos.

\section{Introduction}

Different finishing systems are routinely exploited in the sheep farming sector aiming at maximizing the economic efficiency coupled with the balance between quality and productivity. The high demand for quality of the current consumer market and the search for maximum efficiency in production often leads producers to hesitate in choosing the system to be adopted.

Factors such as animal category, management, feeding, among others, which compose the production systems, are of great importance in lamb finishing and determinants for the final carcass quality. According to Carvalho et al. (2007), lamb is the animal category that presents the highest efficiency for gain coupled with carcass quality, and the use of an appropriate finishing system can optimize these aspects.

Studies on carcass quality have been increasing in Brazil, as well as on factors that affect its quality
(LEMES et al., 2014). However, few studies have been conducted to compare the different lamb finishing systems (POLI et al., 2008). The use of cultivated pastures and confinement are among the most common lamb finishing systems for sheep production, providing good productive indices and carcasses of a better quality (CARVALHO et al., 2007).

According to Pinheiro et al. (2007), in vivo and carcass biometry of sheep is a practical and economical method, allowing comparisons between breed types, weights, and finishing systems. The nutritional status and the measurement of body measures reflect the productive capacity of the animal, being able to reduce economic losses and provide the correct valuation of animals for meat production (SILVA et al., 2016). According to Souza et al. (2009), biometric measures also serve to estimate live weight and body compactness of cut sheep, regardless of sex, breed, and age. 
Productive and quality aspects of lamb meat are directly related to quantitative and qualitative carcass characteristics. With the great diversity of finishing systems, the characteristics are highly variable and often compromise the final carcass quality. According to Alves et al. (2013), factors such as feeding, genetics, and health of sheep influence carcass characteristics and body composition of animals and, when coupled, contribute to a better profitability of the production systems.

Carcass division into commercial cuts is a relevant process of valuing meat for commercialization. Aiming to improve the qualitative and quantitative aspects, it is of great importance the knowledge of the tissue composition of carcass cuts, which facilitates the commercialization and provides a higher degree of consumer satisfaction (LEMES et al., 2014).

The aim of this study was to assess the influence of different finishing systems on the in vivo measurements, quantitative and qualitative carcass characteristics, commercial cut ratio, and shoulder tissue composition of lambs.

\section{Material and Methods}

Time, place, and ethical statement

This study was carried out from August 2015 to January 2016 at the Laboratory of Sheep of the Department of Animal Science of the Federal University of Santa Maria(UFSM), Santa Maria, RS, Brazil. The region, physiographically denominated as Central Depression, has an altitude of $95 \mathrm{~m}$, latitude of $29^{\circ} 43^{\prime} \mathrm{S}$, and longitude of $53^{\circ} 42^{\prime} \mathrm{W}$, with the climate classified as $\mathrm{Cfa}$ (subtropical humid) according to the Köppen classification (MORENO, 1961). This research was approved by the Ethics Committee on the Use of Animals of UFSM under the protocol No. 7118230616, according to the standards of the National Council for the Control of Animal Experimentation.

\section{Animals and experimental diets}

All the animals in the experiment were properly dewormed and vaccinated against clostridiosis. Thirty-eight male, intact lambs from the crossbreeding between the Texel and Ile de France breeds were used, being 16 suckling lambs and 16 weaned lambs at 45 days of age, with the same genotype and contemporaneous. The suckling lambs were randomly distributed with their respective mothers to compose two finishing systems with eight replications each: suckling lambs on pasture and suckling lambs in confinement. Similarly, weaned lambs were distributed in two more finishing systems: weaned lambs fed roughage and weaned lambs fed concentrate. All the animals had access to water and mineral salt ad libitum.

For suckling lambs on pasture, an area of 1.18 ha was used and the diet was composed exclusively of winter grassland characterized by ryegrass (Lolium multiflorum). For suckling lambs in confinement, a covered sheepfold with slatted wooden floor divided into two collective stalls was used and the diet was composed of tifton hay (Cynodon spp.) supplied ad libitum and ground corn (Zea mays) in an amount equivalent to $15.0 \mathrm{~g} \mathrm{~kg}^{-1}$ of the live weight of sheep. The lambs and their respective mothers of this system were fed privately ad libitum with a concentrate composed of corn bran and soybean (Glycine max) meal. The weaned lambs were allocated in a covered sheepfold divided into four collective slatted wood floor stalls. The diet of weaned lambs fed roughage was exclusively composed of alfalfa hay (Medicago sativa) supplied ad libitum. For weaned lambs fed concentrate, the diet was supplied ad libitum and was composed of oat grain (Avena sativa) and $100.0 \mathrm{~g} \mathrm{~kg}^{-1}$ of a concentrate of soybean meal. Table 1 shows the bromatological composition of the foods used to compose the different finishing systems, which are listed in the Table of Valadares Filho et al. (2017). 


\section{Parameters of the in vivo assessments}

As lambs reached the live weight at slaughtering of $30 \mathrm{~kg}$, they were weighed to obtain the farm live weight (LWFrm) and submitted to a 12-hour fasting of solids in order to obtain the fasting live weight (LWF). The fasting break rate (FBR) was obtained by the following equation: FBI $=[100-((\mathrm{LWF}$ $\times 100) /$ LWFrm)]. Subsequently, the following in vivo measurements were performed: body length, forelimb height, hindlimb height, thoracic perimeter, conformation, and body condition score, as the methodology described by Osório et al. (1998).

Table 1. Bromatological composition of foods used in the different finishing systems.

\begin{tabular}{lccccccc}
\hline $\begin{array}{c}\text { Item } \\
\left(\mathrm{g} \mathrm{kg}^{-1} \mathrm{DM}\right)\end{array}$ & $\begin{array}{c}\text { Ryegrass } \\
\text { pasture }\end{array}$ & Tifton hay & Alfalfa hay & Corn grain & $\begin{array}{c}\text { Soybean } \\
\text { meal }\end{array}$ & Oat grain & Salt \\
\hline $\mathrm{DM}$ & 196.7 & 888.6 & 887.1 & 889.3 & 886.2 & 876.6 & 100 \\
$\mathrm{OM}$ & 904.5 & 931.8 & 889.3 & 988.0 & 932.1 & 934.7 & - \\
$\mathrm{CP}$ & 189.1 & 91.2 & 196.3 & 89.9 & 488.2 & 151.9 & - \\
$\mathrm{EE}$ & 35.4 & 15.3 & 23.1 & 45.1 & 19.6 & 41.3 & - \\
$\mathrm{MM}$ & 98.1 & 75.1 & 93.6 & 12.9 & 65.0 & 13.6 & 100 \\
$\mathrm{CF}$ & 275.0 & 346.5 & 288.6 & 24.2 & 59.6 & 89.4 & - \\
$\mathrm{NFE}$ & 449.7 & 452.2 & 363.9 & 846.4 & 306.1 & 696.6 & - \\
$\mathrm{CHO}$ & - & 821.0 & 656.2 & 859.9 & 455.8 & 789.0 & - \\
$\mathrm{NDF}$ & 519.1 & 775.6 & 476.0 & 111.6 & 145.5 & 284.1 & - \\
$\mathrm{ADF}$ & 258.9 & 460.4 & 389.3 & 33.7 & 90.9 & 236.0 & - \\
$\mathrm{TDN}$ & 646.3 & 576.2 & 579.5 & 825.0 & 811.9 & 752.4 & - \\
$\mathrm{Ca}$ & 4.9 & 4.8 & 11.9 & 0.3 & 2.9 & 1.3 & - \\
$\mathrm{P}$ & 2.6 & 1.8 & 2.0 & 3.4 & 5.7 & 3.9 & - \\
\hline
\end{tabular}

Source: Valadares Filho et al. (2017).

$\mathrm{DM}=$ Dry matter; $\mathrm{OM}=$ Organic matter; $\mathrm{CP}=$ Crude protein; $\mathrm{EE}=$ Ethereal extract; $\mathrm{MM}=$ Mineral matter; $\mathrm{CF}=\mathrm{Crude}$ fiber; $\mathrm{NFE}=$ Nitrogen-free extract $; \mathrm{CHO}=$ Total carbohydrates; $\mathrm{NDF}=$ Neutral detergent fiber; $\mathrm{ADF}=\mathrm{Acid}$ detergent fiber; $\mathrm{TDN}=\mathrm{Total}$ digestible nutrient observed; $\mathrm{Ca}=$ Calcium; $\mathrm{P}=$ Phosphorus.

\section{Parameters of carcass assessments}

Lambs were stunned and the slaughter was carried out. Subsequently, the carcasses were weighed to obtain the hot carcass weight. By the ratio between the fasting live weight and hot carcass weight (HCW), the hot carcass yield (HCY) was calculated by $\mathrm{HCY}=[(\mathrm{HCW} / \mathrm{LWF}) \times 100]$. The carcasses were refrigerated at $2{ }^{\circ} \mathrm{C}$ for 24 hours. After the cooling period, the carcasses were weighed again to obtain the cold carcass weight (CCW) and the cold carcass yield $(\mathrm{CCY})$ was calculated by $\mathrm{CCY}=$ $[(\mathrm{CCW} / \mathrm{LWF}) \times 100]$. The cooling break rate $(\mathrm{CBR})$ was calculated by the following equation: $\mathrm{CBI}=$ $[100-((\mathrm{CCW} / \mathrm{HCW}) \times 100)]$. For calculating the carcass compactness index, cold carcass weight was divided by carcass length.

At the same moment when the cold carcass was being weighed, the subjective characteristics of the carcass were measured on a scale of 1 to 5 , such as fatness $(1=$ excessively lean to $5=$ excessively fat $)$ and carcass conformation $(1=$ very poor to 5 = excellent), according to Osório et al. (1998). Subsequently, the carcasses were longitudinally sectioned in the middle, thus obtaining two halfcarcasses.

In the left half, the following carcass measurements were performed, according to Osório 
et al. (1998): carcass length, measured as the distance between the anterior edge of the ischiopubic symphysis and the anterior edge of the first rib at its midpoint; leg length, measured between the anterior edge of the ischio-pubic symphysis and the middle portion of the tarsal bones; leg width, measured between the distance from the inner and outer edges of the upper leg at its widest part; leg depth, measured as the longest distance between the proximal and distal edges of the leg; and chest depth, measured between the back and the sternal bone, i.e. between the region of the sternal crosses in their maximum distance.

In the Longissimus dorsi muscle, exposed through a transversal cut between the 12th and 13th ribs, the following subjective measurements were taken on a scale of 1 to 5, according to Osório et al. (1998): marbling $(1=$ nonexistent to $5=$ excessive $)$, texture $(1=$ very rough to $5=$ very thin $)$, and color $(1=$ light pink to $5=$ dark red). In addition, the subcutaneous fat thickness was measured through a manual caliper.

In the right half carcass, a regional separation of each cut (neck, shoulder, rib, and leg) was performed according to Osório et al. (1998). Subsequently, these cuts were individually weighed and their proportions calculated in relation to the cold carcass weight. Shoulders were dissected in fat, bone, muscle, and other (vessels, nerves, lymph nodes, tendons, aponeuroses, and fascias) in order to determine the tissue composition, according to Colomer-Rocher et al. (1988).

\section{Statistical analysis}

The experimental design was a completely randomized design with four treatments and eight replications. The data were submitted to analysis of variance and F-test and, when significant, the means were compared by the Tukey's test at 5\% significance. The mathematical model used was $\mathrm{Y}_{\mathrm{ij}}$ $=\mu+\alpha_{i}+e_{i j}$, where $Y$ is the dependent variable, $\mu$ is the general mean, $\alpha$ is the effect of the finishing system, $\mathrm{e}$ is the experimental error, $\mathrm{i}$ is the treatment index, and $\mathrm{j}$ is the replication index.

The errors were submitted to the normality test of Shapiro-Wilk $(\mathrm{P}<0.05)$ and, when not normal, the influential observations (outliers) were excluded. The statistical analyses were performed using the software SAS Institute Inc. (2016) version 3.6.

\section{Results and Discussion}

The in vivo biometry, associated with the subjective assessment of the body condition score and conformation, as well as the assessments performed on slaughtered animals, are important tools to determine the ideal moment of slaughtering animals (ALVES et al., 2013). Table 2 shows the values of the means and standard deviations of the in vivo measurements of lambs in the different finishing systems. A significant difference $(\mathrm{P}<0.05)$ was observed between the finishing systems for the variables hindlimb height and thoracic perimeter, and the other in vivo biometric variables did not differ significantly between systems.

Table 2. Means and standard deviations of in vivo measurements of lambs in different finishing systems.

\begin{tabular}{|c|c|c|c|c|c|c|}
\hline \multirow{2}{*}{ Variable } & \multicolumn{4}{|c|}{ Finishing system } & \multirow{2}{*}{ CV (\%) } & \multirow{2}{*}{ P-value } \\
\hline & SP & $\mathrm{SC}$ & WR & WC & & \\
\hline LWFrm (kg) & $30.89 \pm 1.61$ & $30.07 \pm 0.53$ & $31.87 \pm 1.48$ & $30.42 \pm 0.85$ & 4.07 & 0.063 \\
\hline LWF (kg) & $29.00 \pm 1.55$ & $28.93 \pm 0.79$ & $30.01 \pm 1.77$ & $28.37 \pm 1.97$ & 5.26 & 0.318 \\
\hline FBR $\left(\mathrm{g} \mathrm{kg}^{-1}\right)$ & $61.0 \pm 12.1$ & $38.0 \pm 18.7$ & $58.5 \pm 32.4$ & $68.2 \pm 41.2$ & 48.0 & 0.254 \\
\hline $\mathrm{BL}(\mathrm{cm})$ & $60.75 \pm 4.30$ & $62.50 \pm 4.93$ & $64.37 \pm 5.21$ & $59.86 \pm 3.90$ & 7.48 & 0.258 \\
\hline
\end{tabular}

continue 
continuation

\begin{tabular}{lcccccc} 
FH $(\mathrm{cm})$ & $58.50 \pm 1.41$ & $59.57 \pm 1.13$ & $59.37 \pm 2.13$ & $59.00 \pm 3.16$ & 3.54 & 0.761 \\
HH $(\mathrm{cm})$ & $57.00 \pm 2.08^{\mathrm{b}}$ & $60.37 \pm 1.19^{\mathrm{a}}$ & $61.00 \pm 2.27^{\mathrm{a}}$ & $58.86 \pm 2.80^{\mathrm{ab}}$ & 3.60 & 0.006 \\
TP $(\mathrm{cm})$ & $80.57 \pm 3.05^{\mathrm{b}}$ & $86.12 \pm 4.09^{\mathrm{ab}}$ & $90.50 \pm 6.50^{\mathrm{a}}$ & $82.00 \pm 2.74^{\mathrm{b}}$ & 5.35 & 0.002 \\
CONF $(1-5)$ & $3.39 \pm 0.93$ & $3.48 \pm 0.26$ & $3.26 \pm 0.69$ & $2.76 \pm 0.56$ & 21.3 & 0.231 \\
BCS $(1-5)$ & $3.27 \pm 0.65$ & $3.32 \pm 0.25$ & $3.15 \pm 0.62$ & $2.80 \pm 0.22$ & 15.4 & 0.184 \\
\hline
\end{tabular}

Means followed by the same letter in the row do not differ from each other by the Tukey's test at $5 \%$.

$\mathrm{SP}=$ Suckling lambs on ryegrass pasture; $\mathrm{SC}=$ Suckling lambs in confinement; $\mathrm{WR}=$ Weaned lambs fed an exclusive roughage diet; $\mathrm{WC}=$ Weaned lambs fed an exclusive concentrate diet; $\mathrm{LWFrm}=$ Farm live weight; $\mathrm{LWF}=$ Fasting live weight; FBR = Fasting break rate; $\mathrm{BL}=$ Body length; $\mathrm{FH}=$ Forelimb height; $\mathrm{HH}=$ Hindlimb height; $\mathrm{TP}=$ Thoracic perimeter; $\mathrm{CONF}=\mathrm{Conformation}$; $\mathrm{BCS}=$ Body condition score $\mathrm{CV}=$ Coefficient of variation .

The results of hindlimb height are in accordance with those of Pinheiro et al. (2007) and Alves et al. (2013), who found average values of 59.75 and $61.23 \mathrm{~cm}$, respectively. Suckling lambs on pasture presented an average of $57.00 \mathrm{~cm}$ for hindlimb height, a value similar to $58.86 \mathrm{~cm}$ for weaned lambs fed concentrate and lower than 60.37 and 61.00 $\mathrm{cm}$ found for suckling lambs in confinement and weaned lambs fed roughage, respectively. Suckling lambs on pasture reached the slaughter weight in a shorter time (83 days) when compared to suckling lambs in confinement, weaned lambs fed roughage, and weaned lambs fed concentrate, which presented an average of 107 days and a higher bone growth. Silva et al. (2016) worked with diets with different substitution levels of corn by guava by-product in lamb finishing and found average values of 71.65 $\mathrm{cm}$ for hindlimb height.

When studying lamb biometry and its correlations, Castro et al. (2012) observed that the thoracic perimeter is the measure that is better correlated with animal live weight. Thus, the difference found in our study for thoracic perimeter between treatments was not expected since the live weight at slaughtering in the experiment was preset, with no difference for farm live weight. Castro et al. (2012), Alves et al. (2013), and Silva et al. (2016) worked with lambs of the Santa Ines breed and found average values for the thoracic perimeter of $56.14,65.91$, and $71.80 \mathrm{~cm}$, respectively, which are lower than that found in our experiment due to the smaller size breed used by these authors.

The values found and shown in Table 3 for hot and cold carcass weight were higher in suckling lambs than in weaned lambs. The hot and cold carcass yield did not differ between suckling lambs and weaned lambs fed concentrate but differed from weaned lambs fed roughage. This fact may have occurred due to a higher gastrointestinal content of weaned lambs fed roughage in relation to the others. Fernandes et al. (2008) assessed the influence of four production systems on lamb carcass characteristics and found averages of $423.5 \mathrm{~g} \mathrm{~kg}^{-1}$ for hot carcass yield and $401.7 \mathrm{~g} \mathrm{~kg}^{-1}$ for cold carcass yield in weaned lambs on ryegrass pasture. Lima et al. (2013) studied the interference of a high-grain diet on the carcass characteristics of weaned lambs of the Texel breed and found averages of 487.0 and 471.6 $\mathrm{g} \mathrm{kg}^{-1}$ for hot and cold carcass yield, respectively. These yields are similar to those found in our study with suckling lambs, evidencing the high potential of finishing suckling lambs in relation to weaned lambs in the sheep meat production process. Weaned lambs fed roughage diets presented inferior results for hot and cold carcass yield.

The carcass of suckling lambs on pasture and in confinement presented lower values of cooling break rate, with values of 29.1 and $30.0 \mathrm{~g} \mathrm{~kg}^{-1}$, respectively, differing significantly $(\mathrm{P}<0.05)$ from weaned lambs fed roughage and concentrate, with values of 39.8 and $38.1 \mathrm{~g} \mathrm{~kg}^{-1}$, respectively, 
showing a better rate when finished as suckling lambs (Table 3). According to Lima et al. (2013), values of cooling break rate ranging from 30.0 to $40.0 \mathrm{~g} \mathrm{~kg}^{-1}$ are considered as acceptable.

Regarding the variable leg length, a difference $(\mathrm{P}<0.05)$ was observed between the finishing systems, in which the average value of $35.71 \mathrm{~cm}$ found for suckling lambs in confinement was higher than that of $26.56 \mathrm{~cm}$ found for weaned lambs fed roughage. The average leg length of weaned lambs fed roughage was lower when compared to the results found by Motta et al. (2016) and Fernandes et al. (2008). These first authors worked with weaned lambs on ryegrass pasture and found an average value of $33.27 \mathrm{~cm}$ for leg length, and the second authors found an average of $38.17 \mathrm{~cm}$ when working with confined lambs. This variable was more influenced by feeding than the age of lambs since weaned lambs fed only roughage presented the smallest leg length, whose value was lower when compared to those found in the mentioned literature, whereas the other values are close. This behavior was also observed for leg and chest depth. The value of $10.51 \mathrm{~cm}$ found for leg depth, as well as the value of $17.24 \mathrm{~cm}$ found for chest depth, in weaned lambs fed roughage were different and lower when compared to those found suckling lambs on pasture and in confinement. These variables are more influenced by feeding. Lambs fed alfalfa had lower values, with an inferior development than the others. The value of $14.50 \mathrm{~cm}$ found in our experiment for leg depth in both suckling lamb systems (pasture and confinement) was higher than the average values found by Lima et al. (2013) and Motta et al. (2016), with values of 12.22 and 11.76 $\mathrm{cm}$, respectively. The values of 24.00 and 23.66 $\mathrm{cm}$ for chest depth found for suckling lambs on pasture and in confinement, respectively, are similar to those found by Fernandes et al. (2008). These authors found average chest depths of $24.36 \mathrm{~cm}$ in lambs finished on pasture or in confinement.

Table 3. Means and standard deviations of the quantitative carcass characteristics of lambs in different finishing systems.

\begin{tabular}{|c|c|c|c|c|c|c|}
\hline \multirow{2}{*}{ Variable } & \multicolumn{4}{|c|}{ Finishing system } & \multirow{2}{*}{ CV $(\%)$} & \multirow{2}{*}{ P-value } \\
\hline & SP & $\mathrm{SC}$ & WR & $\mathrm{WC}$ & & \\
\hline $\mathrm{HCW}(\mathrm{kg})$ & $14.07 \pm 1.19^{\mathrm{a}}$ & $14.15 \pm 0.74^{\mathrm{a}}$ & $12.21 \pm 0.36^{\mathrm{b}}$ & $11.07 \pm 0.47^{b}$ & 6.01 & $<.0001$ \\
\hline $\mathrm{HCY}\left(\mathrm{g} \mathrm{kg}^{-1}\right)$ & $484.6 \pm 17.2^{\mathrm{a}}$ & $495.3 \pm 27.2^{\mathrm{a}}$ & $416.6 \pm 20.6^{\mathrm{b}}$ & $451.5 \pm 70.7^{\mathrm{ab}}$ & 8.49 & 0.002 \\
\hline CCW (kg) & $13.28 \pm 0.59^{\mathrm{a}}$ & $13.72 \pm 0.70^{\mathrm{a}}$ & $11.75 \pm 0.41^{\mathrm{b}}$ & $10.64 \pm 0.48^{c}$ & 4.53 & $<.0001$ \\
\hline $\mathrm{CCY}\left(\mathrm{g} \mathrm{kg}^{-1}\right)$ & $465.7 \pm 11.4^{\mathrm{a}}$ & $479.3 \pm 23.9^{\mathrm{a}}$ & $400.9 \pm 19.4^{b}$ & $434.2 \pm 67.1^{\mathrm{ab}}$ & 8.34 & 0.002 \\
\hline $\mathrm{CBR}\left(\mathrm{g} \mathrm{kg}^{-1}\right)$ & $29.1 \pm 3.1^{\mathrm{b}}$ & $30.0 \pm 4.5^{b}$ & $39.8 \pm 3.3^{\mathrm{a}}$ & $38.1 \pm 4.4^{\mathrm{a}}$ & 11.4 & $<.0001$ \\
\hline $\mathrm{CL}(\mathrm{cm})$ & $53.31 \pm 2.68$ & $54.92 \pm 1.28$ & $55.37 \pm 1.25$ & $54.14 \pm 1.18$ & 3.40 & 0.257 \\
\hline LL (cm) & $32.62 \pm 2.52^{\mathrm{ab}}$ & $35.71 \pm 0.39^{\mathrm{a}}$ & $26.56 \pm 10.02^{b}$ & $32.86 \pm 1.37^{\mathrm{ab}}$ & 17.0 & 0.020 \\
\hline $\mathrm{LW}(\mathrm{cm})$ & $9.37 \pm 1.09$ & $8.44 \pm 1.82$ & $7.69 \pm 2.45$ & $8.43 \pm 1.02$ & 20.5 & 0.308 \\
\hline $\mathrm{LD}(\mathrm{cm})$ & $14.50 \pm 1.51^{\mathrm{a}}$ & $14.50 \pm 0.50^{\mathrm{a}}$ & $10.51 \pm 4.28^{\mathrm{b}}$ & $13.12 \pm 1.05^{\mathrm{ab}}$ & 19.7 & 0.019 \\
\hline $\mathrm{CD}(\mathrm{cm})$ & $24.00 \pm 1.61^{\mathrm{a}}$ & $23.66 \pm 0.82^{\mathrm{a}}$ & $17.24 \pm 7.02^{\mathrm{b}}$ & $20.86 \pm 1.60^{\mathrm{ab}}$ & 18.8 & 0.011 \\
\hline SFT (mm) & $1.28 \pm 0.49$ & $1.22 \pm 0.70$ & $1.00 \pm 0.01$ & $0.78 \pm 0.39$ & 44.6 & 0.216 \\
\hline $\mathrm{CCI}\left(\mathrm{kg} \mathrm{cm}^{-1}\right)$ & $0.25 \pm 0.01^{\mathrm{a}}$ & $0.24 \pm 0.01^{\mathrm{a}}$ & $0.21 \pm 0.01^{b}$ & $0.19 \pm 0.01^{b}$ & 3.57 & $<.0001$ \\
\hline
\end{tabular}

Means followed by the same letter in the row do not differ from each other by the Tukey's test at $5 \%$.

$\mathrm{SP}=$ Suckling lambs on ryegrass pasture; $\mathrm{SC}=$ Suckling lambs in confinement; $\mathrm{WR}=$ Weaned lambs fed an exclusive roughage diet; $\mathrm{WC}=$ Weaned lambs fed an exclusive concentrate diet; $\mathrm{HCW}=$ Hot carcass weight; $\mathrm{HCY}=\mathrm{Hot}$ carcass yield; $\mathrm{CCW}=\mathrm{Cold}$ carcass weight; $\mathrm{CCY}=$ Cold carcass yield; $\mathrm{CBR}=$ Cooling break rate; $\mathrm{CL}=$ Carcass length; $\mathrm{LL}=\mathrm{Leg}$ length; $\mathrm{LW}=\mathrm{Leg}$ width; $\mathrm{LD}=$ Leg depth; CD = Chest depth; SFT = Subcutaneous fat thickness; CCI = Carcass compactness index; CV = Coefficient of variation. 
According to Grandis et al. (2016), the carcass compactness index expresses the relationship between weight and length of the carcass, being an indirect conformation measure used in animals of similar live weight to assess muscle production. In our study, suckling lambs presented average values of carcass compactness index higher than to those found for weaned lambs, with values of 0.25 and $0.24 \mathrm{~kg} \mathrm{~cm}^{-1}$ for suckling lambs on pasture and in confinement, respectively, and 0.21 and $0.19 \mathrm{~kg} \mathrm{~cm}^{-1}$ for weaned lambs fed roughage and concentrate, respectively. These results are in accordance with the average values of carcass compactness index found by Lira et al. (2017) and Lemes et al. (2014), who found values of 0.22 and $0.19 \mathrm{~kg} \mathrm{~cm}^{-1}$, respectively.

The variables of carcass length, hindlimb width, and subcutaneous fat thickness did not differ as a function of the finishing systems (Table 3). It is important to note that the high coefficient of variation (44.6\%) found for subcutaneous fat thickness among the animals of the different treatments is possibly due to the type of caliper used (manual), which is not as accurate and precise as an automatic caliper. Although no significant difference $(\mathrm{P}<0.05)$ was found between systems for subcutaneous fat thickness, Lira et al. (2017) commented that when comparing different finishing systems, lambs finished in confinement have a higher subcutaneous fat thickness when compared to animals finished on pasture due to different concentration of energy in the diet and energy expenditure in search of food.

Table 4 shows that among the characteristics related to carcass quality a significant difference $(\mathrm{P}<0.05)$ was found for the variables fatness and carcass conformation, while the variables marbling, texture, and color did not differ when comparing the finishing systems at a 5\% significance level. According to Sañudo and Sierra (1986), fatness is influenced by the management system and type of food. Carcasses of suckling lambs presented an average of 3.27 for fatness, which is higher than the average of 2.33 found for weaned lambs fed concentrate.

Table 4. Means and standard deviations of the qualitative carcass characteristics of lambs in different finishing systems.

\begin{tabular}{|c|c|c|c|c|c|c|}
\hline \multirow{2}{*}{ Variable } & \multicolumn{4}{|c|}{ Finishing system } & \multirow{2}{*}{ CV (\%) } & \multirow{2}{*}{ P-value } \\
\hline & SP & $\mathrm{SC}$ & WR & WC & & \\
\hline FAT (1-5) & $2.68 \pm 0.29^{\mathrm{ab}}$ & $3.27 \pm 0.51^{\mathrm{a}}$ & $3.04 \pm 0.38^{\mathrm{ab}}$ & $2.33 \pm 0.73^{\mathrm{b}}$ & 17.9 & 0.009 \\
\hline CC (1-5) & $2.68 \pm 0.25^{\mathrm{ab}}$ & $3.23 \pm 0.57^{\mathrm{a}}$ & $3.19 \pm 0.42^{\mathrm{a}}$ & $2.53 \pm 0.16^{\mathrm{b}}$ & 13.9 & 0.011 \\
\hline Marbling (1-5) & $1.76 \pm 0.38$ & $1.75 \pm 0.46$ & $1.46 \pm 0.39$ & $1.50 \pm 0.01$ & 22.9 & 0.287 \\
\hline Texture (1-5) & $3.33 \pm 0.26$ & $3.44 \pm 0.49$ & $3.44 \pm 0.49$ & $3.36 \pm 0.38$ & 12.7 & 0.953 \\
\hline Color (1-5) & $3.12 \pm 0.58$ & $2.69 \pm 0.46$ & $2.62 \pm 0.35$ & $2.43 \pm 0.53$ & 17.9 & 0.060 \\
\hline
\end{tabular}

Means followed by the same letter in the row do not differ from each other by the Tukey's test at $5 \%$.

$\mathrm{SP}=$ Suckling lambs on ryegrass pasture; $\mathrm{SC}=$ Suckling lambs in confinement; $\mathrm{WR}=$ Weaned lambs fed an exclusive roughage diet; $\mathrm{WC}=$ Weaned lambs fed an exclusive concentrate diet; FAT $=$ Fatness; $\mathrm{CC}=$ Carcass conformation; $\mathrm{CV}=\mathrm{Coefficient}$ of variation.

Weaned lambs fed concentrate also presented lower values in relation to carcass conformation, with an average value of 2.53 , differing significantly $(\mathrm{P}<0.05)$ from suckling lambs in confinement and weaned lambs fed roughage, which presented averages of 3.23 and 3.19, respectively. The average value of carcass conformation of our experiment was higher when compared to that found by Motta et al. (2016) and similar to that found by Carvalho et al. (2017), who found an average value of 3.03 when working with confined lambs submitted to different inclusion levels of wet brewery residue as a roughage food. When studying the carcass characteristics of Santa Ines sheep of two biotypes, 
Lira et al. (2017) found an average value of 2.57 for carcass conformation, similar to that of suckling lambs on pasture and weaned lambs fed concentrate of our study.

The exclusion of stressful activities such as weaning and a higher nutritional value provided by milk in breastfeeding are factors that contribute to the correct lamb development, thus explaining the best results of quantitative and qualitative carcass characteristics found by both systems with suckling lambs.

The average values of commercial cut ratios and tissue composition of lamb carcass in the different finishing systems are shown in Table 5. The commercial cut ratios did not differ $(\mathrm{P}<0.05)$ between animals from different finishing systems. The values obtained in our study are close to the values found by Carvalho et al. (2007), who worked with weaned lambs of the Texel breed and found values of $83.3,204.5,374.3$, and $338.7 \mathrm{~g} \mathrm{~kg}^{-1}$ for neck, shoulder, rib, and leg, respectively. The results obtained in our research for commercial cut ratio indicate that lambs with the same genetic pattern and slaughtered with similar weights may present similar carcass cut ratios regardless of the adopted finishing system. This result is in accordance with Boccard and Dumont (1960), who observed an anatomical harmony that involves a relative constancy in the body parts regardless of the external morphology of lambs.

Table 5. Means and standard deviations of the commercial cut ratio and shoulder tissue composition of lamb carcass in different finishing systems.

\begin{tabular}{lcccccc}
\hline \multirow{2}{*}{ Variable } & SP & SC & \multirow{2}{*}{ CV (\%) } & \multirow{2}{*}{ P-value } \\
\cline { 2 - 5 } & \multicolumn{7}{c}{ Carcass cut ratio $\left(\mathrm{g} \mathrm{kg}^{-1}\right)$} \\
\hline Neck & $71.5 \pm 7.4$ & $64.6 \pm 9.0$ & $63.7 \pm 9.8$ & $68.7 \pm 6.9$ & 12.5 & 0.2187 \\
Shoulder & $221.9 \pm 15.0$ & $207.3 \pm 7.5$ & $212.7 \pm 15.0$ & $215.4 \pm 12.2$ & 6.11 & 0.1912 \\
Rib & $358.2 \pm 17.2$ & $379.9 \pm 22.5$ & $381.1 \pm 21.2$ & $368.8 \pm 24.7$ & 5.87 & 0.1572 \\
Leg & $348.4 \pm 11.2$ & $348.2 \pm 16.7$ & $342.5 \pm 15.8$ & $347.1 \pm 19.1$ & 4.65 & 0.8745 \\
\hline \multicolumn{7}{c}{ Shoulder tissue composition $\left(\mathrm{g} \mathrm{kg}^{-1}\right)$} \\
Muscle & $562.0 \pm 28.1^{\mathrm{ab}}$ & $537.1 \pm 19.4^{\mathrm{b}}$ & $544.1 \pm 20.0^{\mathrm{ab}}$ & $569.3 \pm 11.9^{\mathrm{a}}$ & 3.72 & 0.0315 \\
Fat & $180.5 \pm 51.2^{\mathrm{ab}}$ & $227.0 \pm 12.3^{\mathrm{a}}$ & $175.6 \pm 27.6^{\mathrm{b}}$ & $146.6 \pm 16.7^{\mathrm{b}}$ & 16.7 & 0.0009 \\
Bone & $183.0 \pm 26.1^{\mathrm{ab}}$ & $174.7 \pm 9.2^{\mathrm{a}}$ & $204.0 \pm 16.6^{\mathrm{b}}$ & $208.5 \pm 23.1^{\mathrm{b}}$ & 10.2 & 0.0268 \\
Other & $74.5 \pm 23.7$ & $61.2 \pm 10.1$ & $76.3 \pm 14.7$ & $75.6 \pm 10.9$ & 21.7 & 0.6043 \\
\hline
\end{tabular}

Means followed by the same letter in the row do not differ from each other by the Tukey's test at $5 \%$.

$\mathrm{SP}=$ Suckling lambs on ryegrass pasture; $\mathrm{SC}=$ Suckling lambs in confinement; $\mathrm{WR}=$ Weaned lambs fed an exclusive roughage diet; $\mathrm{WC}=$ Weaned lambs fed an exclusive concentrate diet; $\mathrm{CV}=$ Coefficient of variation.

For the estimation of the tissue composition of carcass, Oliveira et al. (1998) described the shoulder as the portion that presents high coefficients of correlation with its total composition. With the exception of the variable other (ganglia and tendons), all other variables were influenced by the type of finishing system (Table 5). A higher muscle deposition was observed in the shoulder of weaned lambs fed concentrate, with a muscle ratio of $569.3 \mathrm{~g} \mathrm{~kg}^{-1}$, when compared to suckling lambs in confinement, which presented a value of 537.1 $\mathrm{g} \mathrm{kg}^{-1}$. In suckling lambs in confinement, a lower bone composition (174.7 $\mathrm{g} \mathrm{kg}^{-1}$ ) and a higher fat deposition were observed in the shoulder $(227.0 \mathrm{~g}$ $\mathrm{kg}^{-1}$ ) when compared to the weaned lamb systems. Weaned lambs fed concentrate had a higher 
percentage of muscle due to a lower percentage of fat, characterizing a finishing deficit, which is not desirable. In addition, a lower percentage of muscle was observed in suckling lambs in confinement, but the cut as a whole had a better finishing.

\section{Conclusions}

Most of the in vivo measurements and carcass cut ratios are not influenced by finishing systems. Weaned lambs fed an exclusive concentrate diet have lean carcasses with an inferior conformation when compared to those of other finishing systems. Suckling lambs in confinement have shoulders with a higher fat deposition when compared to weaned lambs. Suckling lambs on pasture or in confinement present a superiority in the quantitative carcass characteristics in relation to weaned lambs.

\section{References}

ALVES, D. D.; ARAÚJO, L. M.; MONTEIRO, H. C. F.; LEONEL, F. P.; SILVA, F. V.; SIMÕES, D. A.; GONÇALVES, W. C.; BRANT, L. M. S. Características de carcaça, componentes não-carcaça e morfometria em ovinos submetidos a diferentes estratégias de suplementação. Semina: Ciências Agrárias, Londrina, v. 34, n. 6, p. 3093-3104, 2013.

BOCCARD, R.; DUMONT, B. L. Étude de la production de la viande chez les ovins. Variation de l'importance relative des diférentes régions corporelles de l'agneau de boucherie. Annales de Zootechnie, Les Ulis, v. 9, n. 4, p. 355-363, 1960.

CARVALHO, S.; BROCHIER, M. A.; PIVATO, J.; TEIXEIRA, R. C.; KIELING, R. Ganho de peso, características da carcaça e componentes não carcaça de cordeiros da raça Texel terminados em diferentes sistemas alimentares. Ciência Rural, Santa Maria, v. 37, n. 3, p. 821-827, 2007.

CARVALHO, S.; FRASSON, M. F.; SIMÕES, F. S. B.; BERNARDES, G. M. C.; SIMÕES, R. R.; GRIEBLER, L.; PELlegrin, A. C. R. S.; MENEGON, A. M.; DEPONTI, L. S.; SEVERO, M. M.; MELLO, V. L. Resíduo úmido de cervejaria na terminação de cordeiros em confinamento e seus efeitos sobre as características da carcaça e dos componentes não carcaça. Arquivo Brasileiro de Medicina Veterinária e Zootecnia, Belo Horizonte, v. 69, n. 3, p. 742-750, 2017.
CASTRO, F. A. B.; RIBEIRO, E. L. A.; KORITIAKI, N. A.; MIZUBUTI, I. Y.; SILVA, L. D. F.; PEREIRA, E. S.; PINTO, A. P.; CONSTANTINO, C.; FERNANDES JUNIOR, F. Desempenho de cordeiros Santa Inês do nascimento ao desmame filhos de ovelhas alimentadas com diferentes níveis de energia. Semina: Ciências Agrárias, Londrina, v. 33, n. 2, p. 3379-3388, 2012.

COLOMER-ROCHER, F.; DELFA， R.; SIERRA ALFRANCA, I. Metodo normalizado para el estudio de los caracteres cuantitativos y cualitativos de las canales ovinas producidas en el area mediterranea, segun los sistemas de produccion. Cuadernos INIA, Madrid, n. 17, p. 19-41, 1988.

FERNANDES, M. A. M.; MONTEIRO, A. L. G.; POLI, C. H. E. C.; BARROS, C. S.; RIBEIRO, T. M. D.; SILVA, A. L. P. Características das carcaças e componentes do peso vivo de cordeiros terminados em pastagem ou confinamento. Acta Scientiarum Animal Sciences, Maringá, v. 30, n. 1, p. 75-81, 2008.

GRANDIS, F. A.; RIBEIRO, E. L. A.; MIZUBUTI, I. Y.; BUMBIERIS JUNIOR, V. H.; PRADO, O. P. P.; PINTO, A. P. Características de carcaça e qualidade da carne de cordeiros alimentados com diferentes teores de torta de soja em substituição ao farelo de soja. Ciência Animal Brasileira, Goiânia, v. 17, n. 3, p. 327-341, 2016.

LEMES, J. S.; OSÓRIO, M. T. M.; OSÓRIO, J. C. S.; GONZAGA, S. S.; MARTINS, L. S.; ESTEVES, R. M. G.; LEHMEN, R. I. Características da carcaça e da carne de cordeiros Corriedale manejados em duas alturas de milheto. Archivos de Zootecnia, Cordoba, v. 63, n. 241, p. 161-170, 2014.

LIMA, L. D.; RÊGO, F. C. A.; KOETZ JUNIOR, C.; RIBEIRO, E. L. A.; CONSTANTINO, C.; BELAN, L.; GASPARINE, M. J.; SANCHEZ, A. F.; ZUNDT, M. Interferência da dieta de alto grão sobre as características da carcaça e carne de cordeiros Texel. Semina: Ciências Agrárias, Londrina, v. 34, n. 6, p. 4053-4064, 2013.

LIRA, A. B.; GONZAGA NETO, S.; SOUSA, W. H.; RAMOS, J. P. F.; CARTAXO, F. Q.; SANTOS, E. M.; CÉZAR, M. F.; FREITAS, F. F. Desempenho e características de carcaça de dois biótipos de ovinos da raça Santa Inês terminados a pasto suplementados com blocos multinutricionais. Revista Brasileira de Saúde e Produção Animal, Salvador, v. 18, n. 2, p. 313-326, 2017.

MORENO, J. A. Clima do Rio Grande do Sul. Porto Alegre: Secretaria da Agricultura, 1961. $41 \mathrm{p}$.

MOTTA, J. F.; FERREIRA, O. G. L.; VAZ, R. Z.; COSTA, O. A. D.; ALONZO, L. A. G.; GONÇALVES, M.; LOPES, A. G.; PEDRA, W. U. Desempenho produtivo e qualidade da carcaça de cordeiros avaliados em dois 
sistemas alimentares. Boletim de Indústria Animal, Nova Odessa, v. 73, n. 1, p. 15-23, 2016.

OLIVEIRA, N. M.; OSÓRIO, J. C. S.; MONTEIRO, E. M. Produção de carne em ovinos de cinco genótipos. Composição regional e tecidual. Ciência Rural, Santa Maria, v. 28, n. 1, p. 125-129, 1998.

OSÓRIO, J. C. S.; OSÓRIO, M. T. M.; JARDIM, P. O. C.; PIMENTEL, M. A.; POUEY, J. L. O.; LÜDER, W. E.; CARDELlinO, R. A.; OLIVEIRA, N. M.; GULART, M. A.; BORBA, M. F.; MOTTA, L.; ESTEVES, R.; MONTEIRO, E.; ZAMBIAZI R. Métodos para avaliação da produção de carne ovina: in vivo, na carcaça e na carne. Pelotas: UFPEL, 1998. 98 p.

PINHEIRO, R. S. B.; SILVA SOBRINHO, A. G.; MARQUES, C. A. T.; YAMAMOTO, S. M. Biometria in vivo e da carcaça de cordeiros confinados. Archivos de Zootecnia, Cordoba, v. 56, n. 216, p. 955-958, 2007.

POLI, C. H. E. C.; MONTEIRO, A. L. G. M.; BARROS, C. S.; MORAES, A.; FERNANDES, M. A. M.; PIAZZETTA, H. V. L. Produção de ovinos de corte em quatro sistemas de produção. Revista Brasileira de Zootecnia, Viçosa, MG, v. 37, n. 4, p. 666-673, 2008.

SAÑUDO, C.; SIERRA, I. Calidad de la canal em la especie ovina. Exclusivas ONE, Barcelona, p. 127-153, 1986.

SILVA, N. V.; COSTA, R. G.; MEDEIROS, G. R.; GONZAGA NETO, S.; CÉZAR, M. F.; CAVALCANTI, M. C. A. Medidas in vivo e da carcaça e constituintes não carcaça de ovinos alimentados com diferentes níveis do subproduto agroindustrial da goiaba. Revista Brasileira de Saúde e Produção Animal, Salvador, v. 17, n. 1, p. 101-115, 2016.

SOUZA, E. S.; LEAL, A.; BARIONI, C.; MATOS, A.; MORAIS, J.; ARAÚJO, M.; NETO, O.; SANTOS, A.; COSTA R. Utilização de medidas biométricas para estimar peso vivo em ovinos. Archivos Latinoamericanos de Producción Animal, Venezuela, v. 17, n. 3 e 4, p. 6166, 2009.

STATISTICAL ANALYSIS SYSTEM INSTITUTE SAS INSTITUTE INC. SAS ${ }^{\circledR}$ Studio 3.6: Task Reference Guide. Cary: SAS Institute Inc., 2016. 786 p.

VALADARES FILHO, S. C.; MACHADO, P. A. S.; CHIZZOTTI, M. L.; AMARAL, H. F.; MAGALHÃES, K. A.; ROCHA JUNIOR, V. R.; CAPELLE, E. R. Tabelas brasileiras de composição de alimentos para bovinos. CQBAL 3.0., 2017. Disponível em: <http://cqbal. agropecuaria.ws/index.php>. Acesso em: 19 dez. 2017. 
